DIMENSI, VOL. 8, NO. 2 : 198-209

JULI 2019

ISSN: 2085-9996

\title{
PENGARUH PERSEPSI RISIKO TERHADAP KEPUTUSAN PEMBELIAN ONLINE DI TANJUNGPINANG
}

\section{THE INFLUENCE OF PERCEIVED RISK TO ONLINE PURCHASING DECISIONS IN TANJUNGPINANG}

\author{
Dwi Septi Haryani \\ (Manajemen, STIE Pembangunan Tanjungpinang, Indonesia) \\ dwiseptih@stie-pembangunan.ac.id
}

\begin{abstract}
Abstrak
Dengan berkembangnya teknologi internet dapat memberikan manfaat komunikasi, membuat pengguna internet mudah dalam memperbesar jaringan pemasaran produknya. Dengan mudahnya mengakses internet, banyak hal baru yang ditimbulkan dari perkembangan internet salah satunya pasar online. Internet menunjang para pembisnis untuk memasarkan produknya secara online. Dengan memperhatikan kualitas layanan untuk memperkecil tingkat persepsi risiko untuk meningkatkan keputusan pembelian. Penelitian ini bertujuan untuk menguji pengaruh persepsi risiko, terhadap keputusan pembelian secara online di Tanjungpinang. Objek penelitian ini adalah masyarakat Kota Tanjungpinang. Sampel dalam penelitian ini berjumlah 348 responden yang didapat dengan menggunakan tabel Isaac dan Michael. Instrumen pengumpulan data menggunakan kuesioner. Penelitian ini telah memenuhi syarat validitas dan reliabilitas. Analisis data yang digunakan dalam penelitian ini adalah regresi linier sederhana, uji hipotesis dan analisis koefisien determinasi. Hasil penelitian ini menunjukan bahwa persepsi risiko berpengaruh positif terhadap keputusan pembelian secara online dengan dilihat dari $\left(R^{2}\right)$ sebesar 0,371 yang menunjukan bahwa sebesar 37,1\% keputusan pembelian dipengaruhi oleh persepsi risiko.
\end{abstract}

Kata Kunci: Persepsi Risiko, Keputusan Pembelian, Online

\begin{abstract}
With the development of internet technology can provide communication benefits, making internet users easy in enlarge the network marketing of its products. With easy access to the internet, many new things arising from the development of the Internet one of the online market. The Internet supports the business to market their products online. Taking into account the quality of service to minimize the perception of the risks to improve purchasing decisions. This study aims to examine the effect of risk perception, on purchasing decisions online in Tanjungpinang. The object of this research is a community of Tanjungpinang City. The sample in this study amounted to 348 people obtained using table of Isaac and Michael. The instrument of data collection using questionnaires. This research has fulfilled the validity and reliability requirements The data analysis used in this study is simple linear regression, test hypothesis and analysis of coefficient of determination. The results of this study showed that the perception of risk positively affects online purchasing decisions with the views of 0.371 which shows that $37,1 \%$ of purchasing decisions are influenced by risk perceptions.
\end{abstract}

Keywords: Perceived risk, purchasing decisions, Online 


\section{PENDAHULUAN}

Perkembangan teknologi mengalami kemajuan yang sangat pesat. Kehadiran teknologi internet memberi manfaat komunikasi tanpa batas pada pengguna internet. Dengan mudahnya mengakses internet dimana saja dan kapan saja, memungkinkan banyak hal baru yang ditimbulkan dari perkembangan internet tersebut. Pesatnya perkembangan teknologi saat ini menimbulkan sebuah pemikiran baru bagi pelaku bisnis terutama dalam mengatasi masalah pada sistem penjualan secara konvensional. Hal ini merupakan terobosan guna memajukan perusahaannya dengan memanfaatkan media internet sebagai media promo salah satunya dengan pasar online. Pemasaran elektronik merupakan upaya perusahaan untuk memberikan informasi, melakukan komunikasi, mempromosikan, dan menjual produk dan layanan melalui internet, (Kotler, at al., 2004) dalam (Yusnidar, Samsir, \& Restu, 2014).

Salah satu media komunikasi elektronik yang paling banyak digunakan toko online untuk mempromosikan produk mereka salah satunya adalah melalui jejaring sosial. Namun, untuk mencapai daya tarik, perhatian dari berbagai pasangan mata dan membuat jaringan sosial sebagai kolam yang penuh dengan konsumen, beberapa toko online harus memiliki strategi penting untuk beberapa toko online (Kusumah, 2015). Pertama, mereka perlu memilih jaringan sosial yang tepat bagi mereka untuk mulai mempromosikan produk mereka (Kusumah, 2015).

Selain memberikan keuntungan dan kemudahan, dalam melakukan pembelian secara online juga memiliki keterbatasan-keterbatasan diantaranya konsumen tidak bisa meraba dan merasakan produk yang akan dibelinya sehingga rentan terjadinya penipuan. Maraknya kasus penipuan yang terjadi pada forum jual beli online setidaknya meningkatkan risiko anggapan yang dirasakan konsumen dalam pembelian online. Tan (1999) menemukan bahwa risiko yang dirasakan lebih tinggi ketika membeli produk melalui internet daripada ketika membeli oleh in-Store (Suresh \& Shashikala, 2011). Pernyataan Tan (1999) diperkuat oleh penyataan (Aggarwal, Popli, \& Mishra, 2015), yang menyatakan bahwa Meskipun perdagangan elektronik (ecommerce) meluas, akun penjualan online hanya untuk sebagian kecil dari total 
penjualan eceran. Dari faktor yang mempengaruhi konsumen niat pembelian secara online, salah satunya adalah persepsi risiko.

Terkait dengan adanya kasus penipuan online, maka para pembisnis yang melakukan bisnis secara online harus memperhatikan kualitas layanan jasa online dari segi proses untuk meminimalisir tingkat persepsi risiko konsumen diantaranya dengan menjamin keamanan dan privasi konsumen, dalam berbelanja secara online sehingga keputusan pembelian akan meningkat. Karena menurut (Cunningham, et al., 2005; Liberman and Stashevsky, 2002; Park and Kim, 2003; Miyazaki and Fernandez, 2001) dalam (Suresh \& Shashikala, 2011), Keprihatinan utama belanja online adalah keamanan pembayaran online dan privasi dari informasi personal. Untuk itu, penting bagi para penjual online memperhatikan hal tersebut, dan bagi konsumen yang membeli secara online harus memastikan tingkat keamanan dan masalah data pribadi.

Berdasarkan uraian diatas, maka timbul ketertarikan peneliti untuk menguji dan mengkaji mengenai "Pengaruh Persepsi Risiko Terhadap Keputusan Pembelian Online di Tanjungpinang”.

\section{Rumusan Masalah}

Rumusan masalah yang akan diteliti dalam penelitian ini yaitu: Apakah persepsi risiko berpengaruh positif terhadap keputusan pembelian secara online di Tanjungpinang?

\section{Tujuan Penelitian}

Tujuan kegiatan penelitian ini adalah untuk mengetahui apakah persepsi risiko berpengaruh terhadap keputusan pembelian secara online di Tanjungpinang.

\section{Tinjauan Pustaka}

\section{Persepsi Risiko}

Persepsi risiko berasal dari bidang psikologis dan frase ini awalnya didefinisikan oleh Bauer (Bettman, 1973; Batu \& Gronhaug, 1993; Wu et al., 2011) dalam (Vo \& Nguyen, 2015). Bauer (1967) dalam (Vo \& Nguyen, 2015) menggambarkan bahwa setiap tindakan konsumen akan menghasilkan konsekuensi yang ia tidak dapat mengantisipasi dengan sesuatu yang mendekati kepastian, dan 
beberapa diantaranya cenderung tidak menyenangkan. Dengan kata lain, konsep ini berkaitan dengan situasi di mana pembeli harus menangani ketidakpastian produk baru yang melibatkan baik hasil menguntungkan dan tidak menguntungkan (Stone \& Gronhaug, 1993; Sheau-Fen et al., 2012) dalam (Vo \& Nguyen, 2015). Akibatnya, ketika seorang individu merasa bahwa produk khas berisiko, orang ini dapat menurunkan niat pembelian (Vo \& Nguyen, 2015).

Menurut Featherman dan Pavlou (2002) dalam (Aziz, 2015), persepsi risiko dinilai sebagai tingkat persepsi konsumen akan hasil negatif yang didapat dari transaksi online. Sedangkan menurut Schiffman, et al. (2007) dalam (Suresh \& Shashikala, 2011), Persepsi risiko adalah ketidakpastian yang dihadapi konsumen ketika mereka tidak dapat meramalkan konsekuensi dimasa yang akan datang atas keputusan pembelian yang mereka lakukan.

\section{Indikator Persepsi Risiko}

Dimensi-dimensi yang dipersepsikan dari risiko menurut Liau Xio dalam (Yusnidar et al., 2014) adalah sebagai berikut:

1. Financial Risk, yaitu kerugian yang berhubungan secara finansial yang mungkin dialami sebagai konsekuensi dari pembelian suatu produk.

2. Social Risk, yaitu risiko sosial berhubungan dengan kekhawatiran konsumen akan seperti apa pendapat orang atas pembelian suatu produk yang telah dilakukan.

3. Performance Risk. Yaitu risiko kinerja yang berhubungan dengan kekhawatiran konsumen tentang apakah suatu produk tersebut akan berfungsi sesuai dengan yang diharapkan.

4. Time and Convenience Risk, yaitu risiko yang berhubungan dengan ketakutan atas kerugian dari kehilangan atau tersia-sianya waktu akibat pembelian suatu produk.

5. Physical Risk. Yaitu risiko yang berhubungan dengan kekhawatiran mengenai keamanan produk dan potensi membahayakan diri atau orang lain akibat dari pemakaian suatu produk. 
6. Psychological Risk, yaitu risiko yang berhubungan dengan kekhawatiran kemungkina hilangnya citra diri (self Image) akibat pembelian atau pemakaian suatu produk akibat tidak sesuainya produk dengan kepribadian konsumen atau dengan bagaimana konsumen mempeersepsikan dirinya.

\section{Keputusan Pembelian}

Schiffman dan Kanuk (2004), mendefinisikan keputusan pembeliansebagai pemilihan dari dua atau lebih alternatif pilihan keputusan pembelian. Dengan kata lain, konsumen yang hendak melakukan pilihan harus menentukan pilihan dari berbagai alternatif yang ada (Aziz, 2015). Sedangkan menurut Haubl dan Trifts (2000) mendefinisikan belanja melalui media internet sebagai pertukaran atau aktivitas komputer yang dilakukan seorang konsumen melalui alat penghubung komputer sebagai dasarnya, dimana komputer konsumen terhubung dengan internet dan bisa beinteraksi dengan retailer atau toko maya yang menjual produk atau jasa melalui jaringan (Suhir, Suyadi, \& Riyadi, 2014).

\section{Indikator Keputusan Pembelian}

Menurut (Kotler \& Keller, 2009) pengukuran variabel ini menggunakan indikator sebagai berikut :

1. Pengenalan Masalah, yaitu konsumen mengenali masalah yang akan terjadi nantinya

2. Pencarian Informasi, yaitu konsumen sebelum melakukan pembelian barang terlebih dahulu mencari informasi mengenai sesuatu yang akan dibelinya.

3. Evaluasi Alternatif, yaitu konsumen menggunakan informasi untuk mengevaluasi merek-merek atau barang yang akan dibelinya.

4. Keputusan Pembelian, yaitu keputusan akhir yang dilakukan oleh konsumen dalam melakukan pembelian yang dipengaruhi oleh pandangan risiko seseorang.

5. Perilaku pasca Pembelian, yaitu suatu yang dialami oleh konsumen setelah membeli produk tersebut 


\section{Kerangka Pemikiran}

Kerangka pemikiran dalam penelitian ini adalah sebagai berikut:

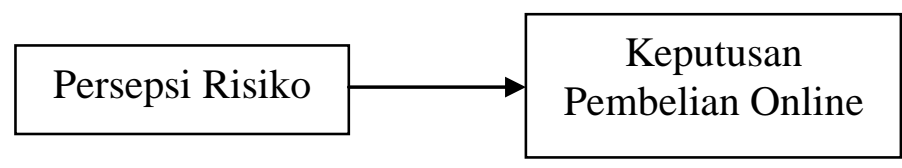

\section{Gambar 1. Kerangka Pemikiran}

Sumber: Konsep yang Disesuaikan untuk Penelitian (2018)

\section{Hipotesis}

Berdasarkan uraian diatas, maka diajukan hipotesis peneliatian sebagai berikut: H1: Diduga bahwa persepsi risiko berpengaruh terhadap keputusan pembelian online di Tanjungpinang.

\section{METODOLOGI}

Penelitian yang dilakukan ini termasuk pada metode penelitian asosiatif dengan pendekatan kuantitatif dan pengolahan datanya menggunakan SPSS 21. Penelitian kuantitatif yaitu data yang berupa angka-angaka (Sugiyono, 2015) agar nantinya dapat dilakukan analisis statistik untuk mengetahui pengaruh persepsi risiko terhadap keputusan pembelian secara online. Metode pengumpulan data menggunakan kuesioner dan studi pustaka melalui jurnal, internet dan lain-lain. Sumber data yang digunakan dalam penelitian ini adalah data primer berupa kuesioner dan data sekunder berupa buku-buku perpustakaan, referensi penelitian sebelumnya dan data dari internet.

\section{Populasi dan Sampel}

Populasi adalah sekelompok orang, kejadian, sesuatu yang mempunyai karakteristik tertentu. Populasi dalam penelitian ini adalah masyarakat kota Tanjungpinang yang berjumlah 260.519 jiwa. Dalam penelitian ini, pengambilan sampel diambil sesuai dengan tabel penentuan jumlah sampel yang dikembangkan dari Isaac dan Michael (Sugiyono, 2015b) yakni untuk tingkat kesalahan 5\% yaitu berjumlah 348 responden. Teknik sampling menggunakan incidental sampling. 


\section{PEMBAHASAN}

\section{Analisis Karateristik Responden}

Dari hasil data yang diperoleh melalui penyebaran kuesioner yang diberikan didapat analisis responden sebagai berikut:

Tabel.1. Karateristik Responden Berdasarkan Usia

\begin{tabular}{|c|c|c|c|}
\hline \multicolumn{4}{|c|}{ Usia Responden } \\
\hline \multirow{7}{*}{ Valid } & & Frequency & Percent \\
\hline & 18-25 tahun & 136 & $39.1 \%$ \\
\hline & 26-36 tahun & 127 & $36.5 \%$ \\
\hline & 36-45 tahun & 64 & $18.4 \%$ \\
\hline & 45-55 tahun & 14 & $4 \%$ \\
\hline & $>56$ tahun & 7 & $2 \%$ \\
\hline & Total & 348 & $100 \%$ \\
\hline
\end{tabular}

Sumber: hasil olahan SPSS 21

Dari data di atas dapat disimpulkan bahwa bahwa persentase usia responden paling banyak terdapat pada rentang usia 18-25 tahun dengan persentase sebesar $39,1 \%$. selanjutnya direntang kelompok umur 26-35 tahun sebesar 36,5\%, lalu usia 3645 tahun sebesar 18,4\%, usia 46-55 tahun sebesar 4\% dan usia >56 tahun sebesar $2 \%$.

Tabel 2. Karateristik Responden Berdasarkan Jenis Kelamin

\begin{tabular}{ccr}
\hline \multicolumn{3}{c}{ Jenis Kelamin } \\
\hline & Frequency & Percent \\
laki-laki & 77 & $77.9 \%$ \\
Valid perempuan & 271 & $22.1 \%$ \\
Total & 348 & $100 \%$ \\
\hline
\end{tabular}

Sumber: hasil olahan SPSS 21

Dari data di atas dapat disimpulkan bahwa karateristik responden berdasarkan jenis kelamin laki-laki sebanyak $22.1 \%$ atau 77 orang sedangkan yang berjenis kelamin perempuan sebanyak $77.9 \%$ atau 271 orang. 


\section{Metode Analisis Data}

\section{Uji Validitas}

Uji validitas yang dilakukan dalam penelitian ini adalah sebagai berikut dan dinyatakan valid apabila $r_{\text {hitung }}>r_{\text {table. }}$

Tabel 3. Hasil Uji Validitas

\begin{tabular}{|c|c|c|c|c|}
\hline Variabel & Butir Pernyataan & $r$ hitung & $\mathrm{r}$ tabel & validitas \\
\hline \multirow{10}{*}{$\begin{array}{c}\text { Persepsi } \\
\text { Risiko (X) }\end{array}$} & PR1 & 0,678 & 0,105001 & valid \\
\hline & PR2 & 0,682 & 0,105001 & valid \\
\hline & PR3 & 0,826 & 0,105001 & valid \\
\hline & PR4 & 0,607 & 0,105001 & valid \\
\hline & PR5 & 0,700 & 0,105001 & valid \\
\hline & PR6 & 0,790 & 0,105001 & valid \\
\hline & PR7 & 0,740 & 0,105001 & valid \\
\hline & PR8 & 0,752 & 0,105001 & valid \\
\hline & PR9 & 0,761 & 0,105001 & valid \\
\hline & PR10 & 0,720 & 0,105001 & valid \\
\hline \multirow{14}{*}{$\begin{array}{c}\text { Keputusan } \\
\text { Pembelian } \\
\text { (Y) }\end{array}$} & KP1 & 0,627 & 0,105001 & valid \\
\hline & KP2 & 0,745 & 0,105001 & valid \\
\hline & KP3 & 0,759 & 0,105001 & valid \\
\hline & KP4 & 0,672 & 0,105001 & valid \\
\hline & KP5 & 0,697 & 0,105001 & valid \\
\hline & KP6 & 0,751 & 0,105001 & valid \\
\hline & KP7 & 0,684 & 0,105001 & valid \\
\hline & KP8 & 0,736 & 0,105001 & valid \\
\hline & KP9 & 0,697 & 0,105001 & valid \\
\hline & KP10 & 0,666 & 0,105001 & valid \\
\hline & KP11 & 0,749 & 0,105001 & valid \\
\hline & KP12 & 0,754 & 0,105001 & valid \\
\hline & KP13 & 0,721 & 0,105001 & valid \\
\hline & KP14 & 0,721 & 0,105001 & valid \\
\hline
\end{tabular}

Sumber: hasil olahan SPSS 21

Dari hasil diatas dapat diketahui bahwa semua indikator yang digunakan untuk mengukur variabel dalam penelitian ini mempunyai koefisiensi korelasi yang lebih besar dari r tabel dan bisa disimpulkan untuk semua indikator tersebut valid (Priyatno, 2012). 


\section{Uji Reliabilitas}

Dalam penelitian ini menggunakan uji reabilitas. Kuesioner dikatakan reliable jika cronbach's alpha $>0,60$ dan dikatakan tidak reliable apabila jika cronbach's alpha $<0,60$ (Priyatno, 2012).

Tabel.4. Hasil Uji Reliabilitas

\begin{tabular}{ccccc}
\hline No & Variabel & Cronbach Alpha & Standar & Reliabilitas \\
\hline 1 & Persepsi risiko $(\mathrm{X})$ & 0,901 & 0,60 & Reliabel \\
2 & Keputusan Pembelian (Y) & 0,925 & 0,60 & Reliabel \\
\hline \multicolumn{2}{l}{ Sumber: hasil olahan SPSS 21 } & &
\end{tabular}

Dari hasil data diatas dapat diketahui bahwa nilai cronbach's lebih besar dari 0,60, yaitu variabel persepsi risiko mempunyai koefisien alpha 0,901>0,60 dan variabel keputusan pembelian mempunyai koefisien alpha 0,925 >0,60. Maka dapat disimpulkan bahwa alat ukur dalam penelitian ini reliabel dan kuesioner yang digunakan cukup handal.

\section{Regresi Linear Sederhana}

Hasil dari data yang di uji dengan menggunakan SPSS 21 untuk mencari analisis korelasi berganda adalah sebagai berikut :

Tabel.5. Analisis Regresi Linier Sederhana

\begin{tabular}{|c|c|c|c|c|c|c|}
\hline \multicolumn{7}{|c|}{ Coefficients $^{a}$} \\
\hline \multirow{2}{*}{\multicolumn{2}{|c|}{ Model }} & \multicolumn{2}{|c|}{ Unstandardized Coefficients } & \multirow{2}{*}{$\begin{array}{c}\text { Standardized } \\
\text { Coefficients } \\
\text { Beta } \\
\end{array}$} & \multirow[t]{2}{*}{$\mathrm{t}$} & \multirow[t]{2}{*}{ Sig. } \\
\hline & & $\mathrm{B}$ & Std. Error & & & \\
\hline \multirow{2}{*}{1} & (Constant) & 22.582 & 2.404 & & 9.394 & .000 \\
\hline & PERSEPSIRISIKO & .851 & .060 & .609 & 14.281 & .000 \\
\hline
\end{tabular}

Sumber : hasil olahan SPSS 21

Berikut persamaan regresinya:

$y=22.582+0.851 x$

Persamaan regresi di atas dapat dijelaskan sebagai berikut: 
$\mathrm{a}=22.582$, adalah nilai konstanta yang artinya ketika variabel $\mathrm{X}$ (persepsi risiko) dianggap konsta atau tidak perubahan maka variabel Y (keputusan pembelian) nilainya akan naik sebesar 22,582.

$\mathrm{b}=0.851$, adalah nilai koefisien regresi dari variabel persepsi risiko artinya jika variabel perspsi risiko naik $1 \%$ maka keputusan pembelian akan meningkat sebesar 0,851 .

\section{Uji Hipotesis}

\section{Uji Parsial (Uji-T)}

Berikut adalah hasil uji parsial (uji-T) yang didapat dari data yang dikumpulkan melalui penyebaran kuesioner yang dilakukan:

Tabel.6. Uji Parsial (Uji-T)

\begin{tabular}{|c|c|c|c|c|c|}
\hline \multicolumn{6}{|c|}{ Coefficients $^{a}$} \\
\hline \multirow[t]{2}{*}{ Model } & \multicolumn{2}{|c|}{ Unstandardized Coefficients } & $\begin{array}{l}\text { Standardized } \\
\text { Coefficients }\end{array}$ & \multirow[t]{2}{*}{$\mathrm{t}$} & \multirow[t]{2}{*}{ Sig. } \\
\hline & $\mathrm{B}$ & Std. Error & Beta & & \\
\hline (Constant) & 22.582 & 2.404 & & 9.394 & .000 \\
\hline PERSEPSIRISIKO & .851 & .060 & .609 & 14.281 & .000 \\
\hline
\end{tabular}

a. Dependent Variable: KEPUTUSANPEMBELIAN

Sumber: hasil olahan SPSS 21

Dari tabel diatas dapat dilihat pengaruh persepsi risiko terhadap keputusan pembelian menunjukan nilai koefisiensi sebesar 0,851 dengan signifikan sebesar 0,000. Nilai signifikan tersebut lebih kecil dari 0,05. Dari nilai t hitung sebesar 14,281 dan nilai $\mathrm{t}$ tabel 1,966844 Dimana $\mathrm{t}$ hitung 14,281 > t tabel 1,966844, hasil tersebut menunjukan bahwa hipotesis yang menyatakan bahwa keputusan pembelian berpengaruh terhadap keputusan pembelian diterima.

\section{Koefisien Determinasi}

Berikut adalah hasil uji koefisien determinasi yang dilakukan dalam penelitian ini: 
Tabel7. Hasil Uji Koefisien Determinasi

\begin{tabular}{l|c|c|c|c|}
\hline \multicolumn{5}{|c}{ Model Summary } \\
\hline Model & $\mathrm{R}$ & R Square & $\begin{array}{c}\text { Adjusted R } \\
\text { Square }\end{array}$ & $\begin{array}{c}\text { Std. Error of the } \\
\text { Estimate }\end{array}$ \\
\hline 1 & $.609 \mathrm{a}$ & \multicolumn{3}{|c}{5.091} \\
\hline a. Predictors: (Constant), PERSEPSIRISIKO \\
\hline \multicolumn{2}{l}{ b. Dependent Variable: KEPUTUSANPEMBELIAN } \\
\hline
\end{tabular}

Sumber : hasil olahan SPSS 21

Dari hasil tersebut diperoleh nilai koefisien determinasi $\left(\mathrm{R}^{2}\right)=0,371$ hal ini menunjukan bahwa sebesar $37.1 \%$ keputusan pembelian konsumen dapat dijelaskan atau dipengaruhi oleh variable persepsi risiko, sedangkan sebesar $62.9 \%$ dijelaskan atau dipengaruhi oleh faktor-faktor lain seperti kepercayaan, kualitas sistem informasi, promosi dan lain-lain.

\section{KESIMPULAN}

Kesimpulan dari penelitian yang dilakukan ini adalah persepsi risiko berpengaruh terhadap keputusan pembelian secara online di Tanjungpinang. Sehingga apabila persepsi risiko semakin baik, maka keputusan pembelian secara online di Tanjungpinang akan meningkat pula.

\section{REFERENSI}

Aggarwal, A., Popli, A., \& Mishra, S. (2015). Literature Based Analysis of Risk Perception of Consumers in E-Commerce: A Study of Online Buying Behavior, (2005), 9-12.

Aziz, V. R. A. (2015). PENGARUH PERSEPSI RISIKO DAN GAYA HIDUP TERHADAP KEPUTUSAN PEMBELIAN PAKAIAN SECARA ONLINE MELALUI BLACKBERRY MESSENGER (BBM). EJounarl Psikologi, 4(1), 95-106.

Kotler, P., \& Keller, K. L. (2009). Manajemen Pemasaran (13th ed.). Jakarta: Erlangga. 
Kusumah, R. (2015). ANALYZE THE EFFECT OF TRUST , PRICE , QUALITY AND PERCEIVED RISK TOWARD CONSUMER PURCHASE BEHAVIOR IN ONLINE SHOPS INSTAGRAM. Jurnal Berkala Ilmiah Efisiensi, 15(05), 355-366.

Priyatno, D. (2012). Cara Kilat Belajar Analisis Data Dengan SPSS 20. Yogyakarta: C.V. Andi Offset.

Sugiyono. (2015). Metode Penelitian Pendidikan: Pendekatan Kuantitatif, Kualitatif dan $R \& D$. Bandung: Alfabeta.

Sugiyono. (2015b). Metode Penelitian Pendidikan Pendekatan Kuantitatif Kualitatif dan R\&D. Bandung: CV. Alfabeta.

Suhir, M., Suyadi, I., \& Riyadi. (2014). PENGARUH PERSEPSI RISIKO, KEMUDAHAN DAN MANFAAT TERHADAP KEPUTUSAN PEMBELIAN SECARA ONLINE ( Survei Terhadap Pengguna Situs Website www.Kaskus.co.id). Jurnal Administrasi Bisnis, 8(1), 1-10.

Suresh, A. M., \& Shashikala, R. (2011). Identifying Factors of Consumer Perceived Risk towards Online Shopping in India. International Conference on Information and Financial Engineering, 12, 336-341.

Vo, T. T. N., \& Nguyen, C. T. K. (2015). Factors Influencing Customer Perceived Quality and Purchase Intention toward Private Labels in the Vietnam Market: The Moderating Effects of Store Image. International Journal of Marketing Studies, 7(4), 51-63. https://doi.org/10.5539/ijms.v7n4p51

Yusnidar, Samsir, \& Restu, S. (2014). Pengaruh kepercayaan dan persepsi resiko terhadap minat beli dan keputusan pembelian produk fashion secara online di kota pekanbaru. Jurnal Sosial Ekonomi Pembangunan, IV(12), 311-329. 